\title{
The Experiences With Nurses Trainings Concerning Prevention of Violence in the Czech Republic in Years 2010-2013
}

\author{
Jaroslav Pekara \\ The College of Nursing; \\ University of South Bohemia \\ Ceske Budejovice; \\ City of Prague Emergency Medical \\ Services, Prague, Czech Republic
}

\author{
Marie Trešlová \\ University of South Bohemia Ceske \\ Budejovice, \\ Ceské Budějovice, \\ Czech Republic
}

\author{
Petr Hulinský \\ Ministry of Education, Youth \\ and Sports, Prague, Czech Republic
}

The aim of this paper is to analyze the results from the implemented projects and trainings which were aimed to minimize violence in health care area in CR (the Czech Republic) in years 2010-2013. The paper describes the results and experience from the communication trainings which were gained within the projects: CR lacks the support of government agencies so as employers and research on the issue, medical staff are not professional enough in communication, there are more requirements for the quality of lecturers; there is no existing general system of monitoring of violent incidents; there is no relevant education at schools. The article contains also new general ways about how to resolve mentioned problems. These results include the special mini project where educated 550 staff members in the health care area in a short time period and taught them key skills for how to approach the aggressive patients-50.6\% respondents used successfully the gained skills in their practice (negotiation with patients, aggressive related); $42.7 \%$ respondents also used successfully the gained skills in their private life. It was found out that with the used skills the courage by conflict resolution was created.

Keywords: violence, research, CR (the Czech Republic), communication, training, prevention

\section{Introduction}

CR (the Czech Republic) has a problem with violence in the health care area. CR lacks the support of government agencies, employers and research on the issue. Gradually, however, efforts have begun to emerge, aiming to minimize violence in health care. In the CR, several projects have been undertaken to minimize violence and the experience from the projects suggests deficiencies in staff training and the importance of educating employees and trying to minimize violence in health care.

The aim of this paper is to analyze the results from the implemented projects and trainings. The author is a medical employee and communication lecturer. He prepares improvements for staff members in the health care and their patients in the $\mathrm{CR}$ on the basis of an analysis and comparison of the relevant projects.

The researches on violence mostly focus on psychiatric hospitals and ICU (Intensive Care Units) and these

Jaroslav Pekara, MSc., R.N., The College of Nursing; University of South Bohemia Ceske Budejovice; City of Prague Emergency Medical Services.

Marie Trešlová, Ph.D., R.N., University of South Bohemia Ceske Budejovice.

Petr Hulinský, Ministry of Education, Youth and Sports. 
data are transferred to non-psychiatry wards automatically (general wards, non-intensive wards). Likewise, the preventive and strategic arrangements are transferred from the ICU and psychiatry wards to the general wards and non-intensive wards. But the general wards are specific in a different way (Beech \& Leather, 2006). The violence seen most often in the general wards is based on escalated negative emotions which get out of control. This type of violent behavior could be de-escalated by proper communication and specific approaches. The health care workers in CR are not trained and skilled enough in such approaches. This is due to the fact that the education at schools is not sufficient (Pekara, 2011).

Three projects (2010-2013) have been implemented in CR for education and prevention of violence in the health care area. The paper describes the results and experience from the communication trainings which were gained within the projects.

\section{Methodology}

Data analyze of existing surveys in CR on the topic violence in the framework of provision of care in health and social system are as follows.

\section{4-2010}

In 2004, research organized jointly by the Ministry of Health and IHPE (Institute of Health Policy and Economics) set out to determine any facts concerning violence in the Czech health care system. The research was planned to continue to the year 2009, but the IHPE was closed down, and so it took place for only two years. During those two years, an empirical quantitative research was carried out among 675 employees in the health care in the CR (Háva et al., 2004).

The study found that violence in the healthcare system in the CR is a serious problem. $42 \%$ of staff members had experience of verbal violence and $13 \%$ staff had experience of physical violence. The incidence of physical violence was the highest in comparison with other countries (Thailand, Bulgaria, Brasil, Libanon, and Portugal). The study contained also qualitative interview with patients who were victims of violence to the medical staff, such as patients who were coming for operations were attacked by medical staff via verbal violence (non-professional communication, arrogant behavior) (Hnilicová, 2007).

This fact was confirmed by means of another qualitative study in 2006 which was aimed to the violence in the emergency medical services in CR. Interviews were performed with the managers of emergency medical services in the CR. The findings are as follows: The verbal aggression is present in every third intervention; physical violence is present in $13 \%$ of all interventions; and $15 \%$ of violent incidents were due to the behavior of the staff of emergency medical services in the $\mathrm{CR}$ (when the staff provoke potential aggressors to the attack due to non-professional communication) (Pekara, 2007).

Within the above-mentioned time, other studies about violence in the health care system in the CR were carried out. Unfortunately, these research undertakings failed to contain valid data and the numbers of respondents were too few.

We can determine the general points in researches in the years 2004-2010:

(1) Violence is a serious problem in the healthcare system in the CR;

(2) Verbal violence prevails over physical violence;

(3) Absence of both central and local data on violence in the healthcare;

(4) The last surveys included a low number of respondents; 
(5) Violent incidents are partly caused by medical staff via their non-professional behavior;

(6) Absence of education in schools.

\section{0-2013}

Czech-Moravian Confederation of Trade Unions started the project called Prevention of Violence in Health and Social Systems in the CR in 2010. It was a quantitative study covering 1,500 employees, which found that violence in the workplace was experienced by $31 \%$ of employees (health and social workers) in the previous year. The physical violence was admitted in $17 \%$ and the psychological violence was admitted in $41 \%$ (mobbing, sexual harassment, bossing, and racial harassment). The number of violent verbal attacks was similar to the number of violence attacks shown in the projects of the year 2004. The incidence of physical violence was even higher. The changes were also in the approach of the management of hospitals and social areas $-60 \%$ managers adopted the measures against the occurrence of violence at their premises (measures associated with the safety and occupational health screening and patient). Unfortunately, there were still persisting deficiencies in the work environment, human resources development, increasing staff numbers, or staff training in communication skills. Even though six years passed from a similar project, the main problems remain the same. That is overworked staff, non-professional communication, and unawareness (Hofmannová, 2010).

Unlike in the first project in 2004, the medical staff wasn't educated practically. Generally, 1,004 staff members in this project, so-called key people for violence in the health care, were educated. Every person was educated during five days: one day in the management of violence, two days in communication skills, and two days in physical self-defense. In this project, an idea to create 14 violence prevention teams should try to minimize violence in individual regions. Unfortunately, this activity currently works only in one region (Pilsen). As time went on, it was found that the education in this project was not effective. The selection of so-called key people did not have any criteria and the five educating days were not effective because many of the 1,004 persons didn't repeat the knowledge gained. The lecturers weren't experts. The lecturers were people from different workplaces and departments, minimum of them worked in the immediate contact with patients. Some educating days were aimed to prevent violence a lot but some educating days weren't aimed at violence at all. Despite the criticism, this project was coming to a greater offer of communication trainings for health care professionals throughout the country, especially in the health care area. Most of the courses were unfortunately one-off, and if they are not repeated, the knowledge and training aren't beneficial for practice.

In the years 2011-2013, another big educational project for medical staff in CR was performed. The organizer of the project was the Ministry of Health plus Aesculap Academy. The project was unique in its practical approach. It was the only educating project without quantitative research, but a great emphasis was placed on the quality and experience of the lecturers. One of the topics of education was the safety of staff members in the health care area. 1,948 staff members in the health care were educated in 26 seminars and nine conferences in total. A mini project was included in this project. 550 health staff members from the hospital in the town of Jihlava were educated in the approach and communication with aggressive patients or their relatives (Kovrzek, 2012). Nurses were educated during 14 seminars (One seminar was for max; 40 staff members and took 120 minutes). The main goal of this mini project was whether is possible to educate staff members in the health care area in a short time period and to teach them key skills for how to approach the aggressive patients. The evaluation was done after 12 months from start of the mini project. Seminars were unique not only because of evaluations but also with the own contain (impact by experiences, influence by 
emotions and infinite number of real situations). The feedback of questionnaires was $42 \%$. Main results: $50.6 \%$ respondents used successfully the gained skills in their practice (negotiation with patients, aggressive related). $42.7 \%$ respondents also used successfully the gained skills in their private life. It was find out that with the used skills the courage by conflict resolution was created. $70 \%$ respondents plan to use the skills in the future.

The development of violence prevention in the Czech Republic in the year 2010-2013 (based on the projects):

(1) The researchers focus on a greater number of respondents;

(2) The frequency of violent incidents stays the same;

(3) Medical staff are not professional enough in communication;

(4) Conferences and seminars more focus on the professionalism in communication;

(5) There are more requirements for the quality of lecturers;

(6) There is no existing general system of monitoring of violent incidents, the medical staff aren't motivated to report any possible incidents;

(7) There is no relevant education at schools;

(8) There is no continuous repetition of the knowledge and skills gained;

(9) If the communicational education is aimed to presentation model situations with real facts, then influence of educational course impacts positive experience and enables change of our behavior.

\section{The Planned Research}

Currently, a small project is running in CR which is targeted only on Prague. Prague wasn't included in previous projects. The project is targeted on TPV (the third party violence) (medical staff, patients, and relations). The main coordinator of project is the Trade Union, and the project takes place with a considerable support by Norway. The main aim of this project is to train 200 medical staff. These people should be educated to become lecturers and educate other people after the project will be finished. The project should be realized without deficiencies shown in previously projects. There was created a five member team of experts-a psychologist with experience in TPV, a lecturer of communication and researcher TPV in CR, a lecturer of self-defense, and the trade union representatives. The psychologist and an expert of TPV are incessantly supervising the preparation of trainings for 200 medical staff (includes 10 organizations provide health or social care). The project started in September 2013 and will end in October 2014. The training will be organized like the interactive seminars. These seminars will prepare medical staff for managing violence incidents in the future. The aim of the project is to train 200 medical staff which should be well-orientated in the problematic of TPV and they should help to deal with the violence incidents at their workplace. Organizer of the project currently plans to create the interventions teams which will be specially educated (Two members from ever organization will be educated in approach of monitoring incidents in their own department and of provide effective feedback after violence incidents).

Medical staff in the project will be trained during five days:

(1) Three days: communication—verbal self-defense, victimology, analysis of TPV incidents;

(2) One day: management of TPV;

(3) One day: physical self-defense — defensive approach, light techniques.

The preparations for this project have revealed several shortcomings that exist in the TPV situation in CR: 
(1) Deficiency of experts and explorers in this field;

(2) Absence of an institution for TPV;

(3) Ignorance of procedures for dealing with TPV at departments;

(4) Low level of national monitoring of TPV;

(5) Measures for TPV are often only temporary.

\section{New General Way?}

Another great contribution for the improvement of mentioned situation should be a dissertation work on this topic. Since 2004, the violence in health care in the CR occurs only in the context of short studies or final reports of the projects. Most of the reports are only for informative purposes - the number of attacks and forms of attacks. Elaboration attacks lack in the studies, also missing test cases and ways how to solve of them. There is an absence of reflection about training days for TPV, many of them have a design such a one-day course. A major drawback is the establishment of a center for the capture of violent incidents - their subsequent analysis by experts and draw conclusions. All of these shortcomings will saturate dissertation, which aims to create a manual for management violence in the health sector in the CR.

Based on the analysis of the foreign literature and practical experience of relevant experts, recommended procedures will be produced to monitor and minimize the problem. There will be also created how to make an effective research, and how to make an effective education for medical staff in this problematic area. We try currently to create system for monitoring violence incidents via special website (currently is under construction) in CR. This is the main point for the optimal start in this problematic. We can present the case interpretation from this system and then we can give several solutions for preventing and solving the situations.

\section{Conclusion}

The violence in $\mathrm{CR}$ is a serious problem. There were seen many situations of non-professional behavior on the side of the medical staff. There is an absence of effective education in approach to aggressive patients and their relations in CR. The professional staff lacks professional approach, the members of the management avoid solving violent situations, and the examples from foreign countries are rarely followed. The projects offered brought forward temporary solutions only and serve as a plaster on the wound rather than a cure. The researches over the past 20 years have shown a positive contribution of education and communication skills training for health professionals. The courses have measurable results and nurses themselves considered them as beneficial. Acquired behavioral skills increase the patient's satisfaction with how the patients learn and understand health care.

As it turns out that any form of repression does not provide qualitative and expected changes, the only possible way to cope with violence is to re-seek practical training in communication with patients and colleagues. An essential part of such trainings must, however, provide feedback, medical personnel must be aware of how to "see" their patient.

\section{References}

Beech, B., \& Leather, P. (2006). Workplace violence in the health care sector: A review of staff training and integration of training evaluation models. Aggression and Violent Behavior, 11, 27-43.

Pekara, J. (2011). Prevence násilí v ošetřovatelství. Prevence úrazů, otrav a násilí, 2, 187-191. 
Háva, P. et al. (2004). Násili na pracovišti v oblasti zdravotnických a sociálních služeb $\check{C} R$ (p. 140). Vstupní teoretické studie, Empirické šetření, Kostelec nad Černými lesy.

Hnilicová, H. (2007). Násilí na pracovišti ve zdravotnictví. Zdravotnické Noviny, 46, 16-18.

Pekara, J. (2007). Napadení zdravotnických záchranářu. Florence, 4, 175-176.

Hofmannová, K. (2010). Pracovní násilí a jeho zdroje. Florence, 11(10), 1.

Kovrzek, T. (2012). A safe healthcare environment with respect to patient-clinic communication. Global Aesculap Academy, Newsletter, $2,7$. 